for nitrogen-fixation from the air by the fungus is very meagre and is not of much consequence. Thus, it is a clear example of close co-operation among the three-the plant, the fungus and the bacteria-for successful and healthy growth of the tree.

I think future work may show if the much discredited mycoplasm theory of Eriksson will be explained by the discovery of hereditary (seed-borne) symbiosis in many plants where a perennial mycelium can be detected within the tegmen of the seeds.

Details of this work, with experimental observations, will be published elsewhere.

1 Gosselin, R., Farlowia, 1, 525 (1944).

"Melin, E., "Tree-Mycorrhiza" (English translation) (Ann. Arbor, Michigan, 1930).

${ }^{3}$ Dennis, R. W. G., Trans. Brit. Mycol. Soc., 29, 11 (1946).

4 Oxley, T. A., and Jones, J. D., Nature, 154, 826 (1944).

${ }^{5}$ Bessey, E. A., "Text Book of Mycology" (Philadelphia, 1935).

${ }^{6}$ How, J. E., Ann. Bot., New Ser., 5, 121 (1941).

'Hahn, G. G., Mycologia, 35, 112 (1943).

${ }^{8}$ Shear, C. L., and Wood, A. K., U.S. Dept. Agric., Bur. Plant Indust. Bull. 252 (1913).

- Campbell, W. A., et al., Tech. Bull. 785, U.S. Dept. Agric. 1 (1942).

${ }^{10}$ Strasburger, "Text Book of Botany" (6th English Edition) (London 1930).

${ }^{1}$ Parkin, E. A., Ann. Appl. Biol., 29, 268 (1942).

${ }^{2}$ Blake, A., Oxford Forestry Mem., No. 14, 5 (1932).

${ }^{13}$ MacDougal, D. T., and Dufrenoy, J., Plant Phys., 19, 440 (1944).

\section{ELECTROSTATIC HAZARDS IN INDUSTRY}

$\mathrm{T}$ HE Institution of the Rubber Industry organised a forum to discuss "Electrostatic Hazards in Industry" on December 9 at the James Watt Memorial Institute, Birmingham. Mr. W. E. Madge (Dunlop Rubber Company) was in the chair, and the proceedings opened with five short papers each dealing with a particular aspect of the electrostatic hazard.

Mr. S. H. Wilkes (H.M. Senior Chemical Inspector of Factories), in his introductory remarks, dealt with the general principles to be borne in mind when considering electrification of materials and the consequent fire or explosion hazard. Inflammable materials-vapour, gas, or finely divided suspensions of dust-ignite only when the concentration lies within certain limits. Within this inflammability range, ignition may be caused by a rise in temperature of only a part of the system or by an electrostatic discharge. The obvious steps to take in minimizing the probability of ignition include the control of concentration and the elimination of the igniting source. Mr. Wilkes emphasized that the former must be considered of first importance; the elimination of explosive concentrations is more easily achieved in practice than the removal of all possible sources of ignition. At the same time, all reasonable steps must be taken to eliminate the occurrence of dangerous amounts of static by earthing securely all conductors, and by installing conductors instead of non-conductors wherever this is practicable.

Dr. F. J. Llewellyn (University of Birmingham) underlined the need for comprehensive laboratory data concerning the electrification and electrostatic ignitibility of substances likely to be met with in industry. Dealing with the theoretical side of ignition of dust clouds by means of electrostatic discharges, he mentioned a possible correlation between the energy stored in a condenser, the rate of dissipation, the voltage-time and current-time characteristics of the resulting air discharge and its incendivity. Dis- charge from a $0.01 \mathrm{mfd}$. condenser when no resistance, other than the leads and the spark gap, is included in the circuit produces an oscillatory current in the gap. The inclusion of a small resistance, say 500 ohms, completely removes this oscillatory nature; at the commencement of the spark, the current rises steeply to a high value, thereafter falling exponentially with time; the voltage meanwhile drops at the commencement of the spark to a low value and remains fairly constant until the spark ceases. The duration of the spark becomes progressively larger as this resistance increases, and the proportion of the condenser energy liberated in the spark rises to a maximum of about 30 per cent at 50,000 ohms, thereafter falling with increasing resistance. The ignition of dust clouds is most easily accomplished with sparks of short duration and high energy, that is, those obtained by discharging a condenser through a resistance of the order of $50,000 \mathrm{ohms}$.

Mr. G. Morris (Imperial Chemical Industries, Ltd., Explosives Division) discussed the electrification of powders in free-fall under gravity (Morris, Proc. Phys. Soc., 51, 1010; 1939) and also the ignition of heaps of powder by electrostatic sparks. The criterion of ignition is the energy stored in the condenser $\left(\frac{1}{2} C V^{2}\right)$, and for small condensers is independent of the capacity. In laying down safety conditions for dealing with explosive powders, Mr. Morris found that 0.05 times the 50 per cent ignition energy gave a reasonably satisfactory upper limit for permissible electrification.

Mr. Fordham Cooper (H.M. Electrical Inspector of Factories) spoke of the causes of electrification in liquids during handling and movement. The boundary of an electrolyte such as water is normally highly polarized, having an electrical double layer, the inner and outer sides of the skin being oppositely charged. Anything which disturbs this surface will upset the electrical balance, with resultant separation of the positive and negative charges. Normally, any charges produced by the disturbance of a liquid will disappear by conduction if the specific resistance is less than $10^{10}-10^{12}$ ohms. The electrification of nonelectrolytes presents a difficult problem; the prob. able explanation lies in the existence of traces of ionic or colloidal material in the liquid. Thus polar liquids such as alcohol or nitrobenzene are particularly susceptible to electrification. Mr. Cooper dealt also with the implication of stirring, and the addition of soaps; and suggested the following as precautions against fire and explosion : $(a)$ increase conductivity of solvents; (b) use high flash point solvents; (c) earth all metal work, bonding discharging to receiving vessels; $(d)$ keep up the air humidity ; $(e)$ do not introduce earthed or even unearthed conductors near the free surface of a liquid.

Mr. D. Bulgin (Research Division, Dunlop Rubber Co., Ltd., Birmingham) discussed the special electro. static problems associated with rubber. Since the specific resistance of rubber lies between $10^{9}$ and $10^{16} \mathrm{ohms}$, the leak-away time of static charges is very great; discharge may proceed either as a series of feeble sparks or as a brush. Whereas this direct discharge is usually of insufficient energy to cause ignition of inflammable vapours, induced charges on nearby conductors can become a serious hazard. Mr. Bulgin outlined the various methods available for minimizing this risk, both in the production of rubber goods and in their utilization. He described also a valve-voltmeter which he has designed (J.Sci. Instr., $22,8 ; 1945)$ which is extremely valuable in detecting 
the build-up of electrostatic voltages and in surveying rapidly the electrification produced at various stages in the processing of a material.

The five papers will be fully published elsewhere in due course.

\section{CENTENARY OF KING'S COLLEGE (LONDON) ENGINEERING SOCIETY \\ THE Engineering Society of King's College,} London, celebrated the centenary of its founda. tion during March 5-8. It is thus one of the oldest institutions of its kind in Great Britain, for its first meeting was preceded by only six days by the inauguration of the Institution of Mechanical Engineers. The oldest engineering institution in Great Britain, the Civil Engineers, was formed in 1818 and received its Royal Charter in 1828 ; the Société des Ingénieurs Civils de France was not formed until 1848.

The celebrations opened on March 5 with a thanksgiving service in the College chapel, conducted by the chaplain, the Rev. S. H. Evans, which was addressed by the Very Rev. W. R. Matthews, Dean of St. Paul's, himself a fellow of the College. This was followed by an address "King's College Engineering Society 1847-1947', delivered by Prof. S. J. Davies in the Great Hall.

Prof. Davies began by reading the resolution passed by the eleven originaI members on February 2 , 1847 : "Resolved that a Society be formed under the sanction of the Principal and with the patronage of the Professors of King's College, London, to be called the King's College Engineering Society, and that its object be to take in the various scientific and engineering periodicals of the day and that it be hereafter extended to the reading of original papers, giving prizes ..."

By the end of 1847 nine papers, on subjects ranging from the Niagara Falls to the solution of algebraic equations, and from daguerreotype to coal gas, had been read. The practice of electing every term a committee and officers from the students was also established.

It is interesting to note that both Prof. Wheatstone, well known for his work on electric communications, and who held the chair of experimental philosophy, and Prof. Daniell, known by his hygrometer and the Daniell cell, who held the chair of chemistry, were among the early teachers in the Department. The subjects taken covered the very wide range of engineering, applied science and architecture. The development of the undergraduate studies has been towards specialization in civil, electrical and mechanical engineering, architecture being discontinued in 1912 and metallurgy in 1918.

There has been a remarkable continuity in the progress of the Society. Apart from the First World War, there have been only two short interruptions. The first was when a Mr. Gilbert moved an amendment, to a proposition dissolving the Society, to form a "Shakespearian and Dramatic Society". This was none other than W. S. Gilbert, of Gilbert and Sullivan fame. This break lasted only two years, however, and the Society was restored to health.

As stated before, one of the objects of the Society is to provide an opportunity for members to read papers of engineering and allied interest. In the last hundred years, more than 1,100 papers have been read, an average of eleven a year. The practice of awarding prizes for papers was instituted in 1871 , and it has been the practice to award two prizes every year since. A third prize, to commemorate the services to the Society of the late Prof. Ernest Wilson, to be awarded for the year's best paper, was established in 1932.

Many former students and members of the Society have risen to eminence in their profession ; of eighty two presidents of the Institution of Civil Engineers, ten have been King's 'engineers'. There have been occasions when King's 'engineers' have achieved fame in other fields; W. S. Gilbert and C. K. Bird, or "Fougasse", of Punch, are notable examples.

In concluding his history of the Society, Prof. Davies mentioned the King's Engineer, which has been published annually under the joint auspices of the Society and of the Engineering Branch of the Old Students' Association.

Prof. Davies ended his address with some remarks on engineering training in general. In particular, he compared the size of technical schools in Britain with those in Germany; he believes that better results are obtained when the engineering faculty continues as a numerically small unit within the larger body of a college.

\section{DEW IN PALESTINE}

N account has been received from Mr. S.Duvdevani, of the Palestine Meteorological Service, of an optical method of estimation of dew which he has developed at the Dew Research Station, Pardess Hanna Agricultural School, Karkur, Palestine. The need was felt for a much quicker and less costly method than that of direct weighing of the dew collected on a standard surface, so that a network of voluntary observing stations could be organised for a country-wide study of the amount of dew in the different seasons. In a dry climate such as that of Palestine, the success of certain crops is largely dependent upon the amount of dew, and the justification for measurements with apparatus not likely to give a high degree of accuracy, in which the personal factor may be rather prominent, is obvious. Agriculturists clearly wish to know primarily where the regions of most abundant dew at the seasons when this is most important are to be found. They care comparatively little about small errors in the absolute values of the figures for the amount of dew.

The optical method arrived at after ten years of study consists in exposing a standard wooden block, called the dew-gauge, at a standard height in the open, from sunset to sunrise. Dew is estimated by reference to a standard atlas of photographs, with which the size, form and distribution of the drops on the gauge is compared. Calibration was based on a preliminary study of the measured weights of dew for various types of drop distribution recorded on life-size photographs of the gauge, a selection of which is doubtless reproduced in the atlas.

A specimen Quarterly Dew Statement published by the Palestine Meteorological Service shows that in 1946 the totals for June varied more than those for April, ranging from about $7 \mathrm{~mm}$. at Ramot $\mathrm{Ha}$ Shavim to practically nil at Jericho. If the year was not a very unusual one meteorologically, the conclusion to be reached is that, in the Rift Valley, crops get very little assistance from dew between April and June, even when there are many clear nights, and that coastal and hill country get dew on a scale unknown in the cloudy climate of England.

E. V. NEWNHAM 